\title{
HISTORY
}

\section{ХУДОЖЕСТВЕННЫЕ ПРОИЗВЕДЕНИЯ В АЗЕРБАЙДЖАНСКОЙ ЛИТЕРАТУРЕ, ПОСВЯЩЕННЫЕ ИМАДЕДДИНУ НАСИМИ}

\author{
Пюста Ахмедова \\ Диссертант Нахчьванского Государственного Университета, Азербайджан
}

DOI: https://doi.org/10.31435/rsglobal_ijitss/31012020/6878

\section{ARTICLE INFO}

Received 13 November 2019 Accepted 10 January 2020

Published 31 January 2020

\section{KEYWORDS}

Azerbaijan literature, poetry, Imadeddin Nasimi, literary image.

\begin{abstract}
As a result of attention and interest to the heritage of Imadaddin Nasimi, the great thinker of the 14th century, numerous works of various genres have been written about the life and creativity of Nasimi. Each of the lyrical, epic and dramatic works dedicated to Imadaddin Nasimi are referred to his creativity and destiny. Reflecting the artistic and philosophical world of Nasimi, it becomes clear from each of these works that Nasimi is one of the greatest literary figures not only of his time, but of Azerbaijani literature as a whole. Other authors such as Islam Safarli, Rasul Rza, Aliagha Kurchayli, Nabi Khazri, Bakhtiyar Vahabzade, Isa Huseynov, Mahmud Ismayil, Ali Tuda, Sohrab Tahir, Jabir Novruz, Qabil, Khalil Rza Uluturk, Fikret Sadig, Kalantar Kalantarli, Isa Ismayilzadeh, Mammad Ismayil, Musa Yagub, Alakbar Salahzadeh who covered the poet's difficult life path, wrote about Nasimi and his time, they turned to the artist's creativity as a primary source, as a result, presented literary works that fully cover the poet's creativity and biography. In each of these works based on the historical principles and dedicated to Nasimi, Nasimi's poetry was analyzed and approached in the context of the period in which it was written. Each of these works is a literary example that gives a full idea of the poet's life and art.
\end{abstract}

Citation: Пюста Ахмедова. (2020) Hudozhestvennye Proizvedeniya v Azerbajdzhanskoj Literature, Posvyashchennye Imadeddinu Nasimi. International Journal of Innovative Technologies in Social Science. 1(22). doi: 10.31435/rsglobal_ijitss/31012020/6878

Copyright: (C) 2020 Пюста Ахмедова. This is an open-access article distributed under the terms of the Creative Commons Attribution License (CC BY). The use, distribution or reproduction in other forums is permitted, provided the original author(s) or licensor are credited and that the original publication in this journal is cited, in accordance with accepted academic practice. No use, distribution or reproduction is permitted which does not comply with these terms.

Введение. Есть такие литературные личности, изучение их творчества и написания произведений, посвященных им имеет важное значение. Одним из таких уникальных личностей является Насими, который написал золотые страницы азербайджанской поэзии XIV века. Насими также является одним из величайших мастеров азербайджанской литературы с древней историей. Поэзия Насими, создающая полное представление о политической картине эпохи с силой философско-художественного мышления, - это уникальный, грандиозный мир, освещающий темные страницы истории. В творчестве Насими воплощаются человек и Вселенная, самое высочайшее художественно-философское выражение духовного мира человека.

Исследователи Творчество Насими.

Академик Бекир Набиев в своей книге «В свете слова Насими» писал: «Славные имена великих мыслителей и владетелей непоколебимой воли в борьбе за свою веру, решительно воспринявшие смерть на этом пути, история написала золотыми линиями на свои страницы, которые не сотрутся веками с памяти народа" (1, стр. 57). Среди таких непоколебимых моджахедов имя великого азербайджанского поэта - мыслителя Имадеддина Насими занимает одно из почетных мест. 
Поэт-мыслитель Имадеддин Насими (1369-1417) — один из величайших литературных лиц не только своего времени, но и многовековой азербайджанской литературы в целом. Образ Насими, его трагическая судьба, глубокое, бесценное художественное наследие, отражающее широту и гуманизм его воззрений, неизменно привлекали к себе внимание деятелей искусства нашей страны. В азербайджанской литературе было создано множество ценных художественных образцов различных жанров (стихи, поэмы, прозы и драматические произведения), созданы многочисленные живописные и скульптурные работы, интересные кинофильмы, новые искусствоведческие исследования.

Такие произведения, по словам академика Исы Габиббейли: «Отражение большого интереса и высокой страсти к выдающемуся творцу в Азербайджане» (2).

Яркое отражение тема Насими получила в поэтическом творчестве. Анализ произведений Ислама Сафарли, Расула Рзы, Алиаги Кюрчайли, Наби Хазри, Бахтияра Вахабзаде, Исы Гусейнова, Махмуда Исмаила, Али Туды, Сохраба Тахира, Джабира Новруза, Габиля, Халила Рзы Улутюрка, Фикрета Садыка, Калантара Калантарли, Исы Исмаилзаде, Мамеда Исмаила, Мусы Ягуба, Алекпера Салахзаде и других авторов является не только подходом к изучению художественного воплощения судьбы Имадеддина Насими, а также оно важно для освещения на языке высокого искусства реалий того времени, в котором жил и творил писатель, а также в целом для решения ряда проблем, связанных с созданием образа литературной личности в художественной литературе. Об Имадеддине Насими в азербайджанской литературе написаны и стихи, и поэмы, и драматические произведения, и романы, и повести.

\section{Литературные произведения, посвященные Насими.}

Когда речь идет об обращении к теме Имадеддина Насими в азербайджанской драматургии, в литературоведении часто упоминается лишь драма “Фарьяд” (Вопль) народного поэта Бахтияра Вахабзаде (1984). Эта драма-не жизнеописание, а свободное повествование о драматической судьбе поэта в том мире косности и жестокости, который его окружал. Тем не менее, исследования показывают, что до «Фарьяда» в нашей драматургии были написаны несколько произведений на эту тему. Стихотворная драма Акпера Мафтуна «Насими» (1946), а также пьеса Фирудина Ашурова «Насими» (1973) относятся также к такому роду произведений.

Произведение «Насими» было написано А. Мафтуном в 1946 году и представлено читателям в опубликованной в 1959-ом году книге автора «Стихотворения» (3). В этой стихотворной драме описывается не весь жизненный путь мыслителя Имадеддина Насими, а последний период его жизни в Халебе. В пьесе описывается, что Насими, после прибывания в Халеб, за короткое время прославляется и здесь, с каждым днем растет число сторонников, поклоняющихся его хуруфизской секте. Насими продолжает обучать молодежь основным навыкам этого обучения, а это в скором времени начинает пугать правящие круги. Высокие должностные лица и духовные лидеры старались, каким бы способом ни было отдалить сторонников и учеников Насими от него, предотвратить широкое распространение суфизма.

Одна из причин популярности Насими, которая преодолевала границы империй, состояла в его гибели за идею, в том, что в борьбе за свои идеи он смог подняться до высоты священного понятия шехида. Представьте, по сведениям исторических источников, в городе Халеб один из учеников Насими, называя себя его именем, читает на площади стихи своего учителя, за что его Муфти приказывает арестовать и приговаривает к казни. Узнав об этом, Насими спешит к месту казни и прилюдно объявляет себя автором этих стихов. Всем известна мученическая смерть поэта, и это свидетельствует о том, что Насими, возвышая несгибаемость и мощь человеческого духа и уподобляя его всемогущему Создателю, не видел себя в стороне от борьбы за честь и достоинство человека. В пьесе А. Мафтун приводил различные сведения из исторических источников, а также ссылался на записанные легенды. Среди драматических произведений, посвященных Имадеддину Насими, своеобразное место занимает пьеса Фирудина Ашурова «Насими» (1973) (4).

Академик Гамид Араслы, ссылаясь на различные средневековые источники, а также на определенные моменты в стихах И.Насими, писал: "Смерть поэта произошла не только из-за его убеждений. Может быть, это связано и с политическими событиями эпохи" (5, с.40). В пьесе Фирудина Ашурова во всех обстоятельствах Насими мы встречаем в вихре политических событий. Пьеса Фирудина Ашурова "Насими" написана прозой. Автор представил произведение как «три действия и четырнадцать картин эпической драмы». В пьесе количество образов составляет более 
тридцати человек. Но, конечно же, художественное произведение не оценивается его объемом, количеством образов. Основной задачей является, как правильно найти художественное решение темы. Как видно, Ф. Ашуров провел определенные творческие поиски, ознакомился с рядом исторических источников и литературных материалов, в том числе с произведениями поэта, а также использовал их в пьесе с целью создания положительного впечатления об эпохе жизни, среде, личности, стремлениях и цели великого мыслителя Имадеддина Насими. Наряду с этим, в произведении особое место занимают события и образы, являющиеся продуктом воображения автора. На протяжении всей пьесы мы встречаем Насими в различных местах и в центре сложных событий. Работая над пьесой «Насими», Фирудин Ашуров старался языком искусства донести до читателей характерные моменты жизни поэта-мыслителя в борьбе. За исключением некоторых ситуаций, можно сказать, что поэт смог достичь своей цели.

Стихотворная драма Бахтияра Вахабзаде «Фарьяд» (6), посвященная Имадеддину Насими, привлекает внимание своей оригинальностью, высокой художественностью и философской глубиной. Пьеса была поставлена на сцену в 1984 году в Азербайджанском Государственном академическом драматическом театре и получила большую заслугу. События в произведении «Фарьяд» происходят вокруг великого мыслителя, мятежного поэта народа, жившего в XIV веке. О Насими говорят как о могучей личности, мастере слова нашего общественно-политического мнения. Происходящие общественно-политические события приводят к бесправию, несправедливости и неравенству людей. В результате повышается вопль голоса людей. Идея, свобода личности составляют основную идею произведения.

В стихотворной драме «Фярьяд» Бахтияра Вахабзаде, состоящей из семи картин, первым делом привлекает внимание бессмертие идей Насими, сила и величие его личности. В произведении описывается, что хуруфизм, который пропагандировал Насими, был широко распространен и в городе Халебе. А это сильно беспокоило правящие круги и духовенство. Основным делом они считали убрать Насими. Многие, кто привил большую любовь к личности и идеям Насими, чтобы не сдать поэта в их руки, готовы были пойти на добровольную смерть, сказав: «Я - Насими». Личность истинного Насими трудно определить.

Немаловажную роль в раскрытии идеи играет диалог между двумя Насими в темнице Галладжи Мусой (Насими I) и Туралом (Насими II). Насими I (Галладжи Муса) относительно старый, видел в арабских краях все стороны жизни, и путь истины нашел в хуруфизме. А Насими II родом из Ширванского региона Азербайджана. Оба из них готовы пойти на смерть в борьбе за Насими, и это считают себе честью. Осознав правду, насимичи до последнего момента защищали свою гордость и величие. Насими II категорически возражает против своего отца, который попросил эмира простить его. Это показывает, что он выбрал этот путь борьбы по своей воле. Из статьи видно, что таких вольных муджахидов как он немало.

В пьесе «Фарьяд» Бахтияр Вахабзаде воспевал насимичей, которые произнеся выражения «Я-истина, Я-Бог» и пожертвовав собой на этом пути, увековечили насиминский дух и его идеи. До тех пор, пока есть жертвы на пути веры Насими, ему нет смерти. Именно это мнение составляет основную цель произведения. Если Насими говорит: «Я-истина, Я-Бог», то его последователи уже говорят: «Я-Насими» и, добровольно идут на смерть за свои намерения и убеждения. «Что такое жизнь?», «А смерть? Какой из них важен? Если смерть служит утверждению идеи, победе намерений и убеждений, разве он не более славен, чем жизнь?» ... В статье сцена смерти является самым высоким моментом протеста против фальшивой жизни, лживой правды. Предпочтение мужественной смерти на подлую жизнь воспевается как критерий философской и духовной мудрости и гармоничной личности» $(7, \mathrm{c} .169)$.

Последний драматический образец в азербайджанской литературе, посвященный Имадеддину Насими - поэтическая драма «Насими» в пяти картинах, написанная поэтом Сайманом Арузом (2019). В произведении представлена историческая картина периода существования литературной личности Насими и суть учения хуруфизма.

В азербайджанской поэзии также написано много стихов и поэм о Имадеддине Насими. Вспомним некоторые из этих стихотворений: Расула Рзы «Насимия», «Насимия, Физулия, Открытое письмо Сабиру», Ислама Сафарли «Насими», Халила Рзы «Как Насими», Алиаги Кюрчайлы «Насими», Джабира Новруза «Насими», Али Туды «Насими», Фикрета Садыга «Беюк Насимия», Исы Исмаилзаде «Монологи памятника Насими», Калантара Калантарли 
«Открылось мое окно», Матлаба Мисира «Поклоняться Насими», Гашама Наджафзаде «Статуя Насими», Эмиля Мехтиева «Ты покоишься в сердцах», Мухтара Гасымзаде «Насими»и др.

Об Имадеддине Насими также написано несколько поэм. Это произведения Мусы Ягуба «Ширванский торговец и Насими» (1968), Алекпера Салахзаде «Статуя огню» (1969), Габиля «Насими» (1964-1973), Сахраба Тахира «Караван уходит» (1973), Расула Рзы «Последняя ночь» (1973-1974), Наби Хазри «Горы, на которые смотрел мой дед» (1976).

В поэме народного поэта Мусы Ягуба «Ширванский торговец и Насими» (8) привлекает внимание встреча Насими с неким ненасытным купцом, приехавщим в Халеб из родного края Насими Ширвана. Купец продает шелк и хочет воспользоваться Насими для заработка денег. Здесь, на чужбине Насими страдает по родине, понюхав ширванский шелк, он чувствует аромат родной страны.

Алекпер Салахзаде символически представил лирико-романтические, ассоциативные мысли о Насими в поэме «Статуя огня» (9) в контексте истории и современности. Вознесенный к виселице в Халебе образ поэта выражается как возвышение окружающей среды, общества и современности. В конце поэмы, автор делает заключение, что кожа, содранная с поэта - это не только лишь ее глубокий вырез, а открытие пути к светлому будущему, к вечности и нравственному бессмертию.

Поэма "Насими" (10), состоящая из трех частей известного поэта Габиля, является более монументальной и всеобъемлющей. Здесь наряду с лирическими мыслями важное место занимают и эпические презентации. Это ценное произведение искусства о жизни Насими, его убеждениях в борьбе за истину. Эта поэма была удостоена Государственной премии Азербайджанской Республики. В поэме выражена большая вера в духовную мощь человека в хуруфизме Насими. В каждой главе произведения есть рисунки, истории, обобщения, относящиеся к этой теме.

Критик Ахмед Гусейнов писал: “Вера в человеческую мощь проходит как красная линия в поэме «Насими» Габиля (11).

В поэме «Насими» Габиля история связана с современностью. Автор представил Насими, о котором мы знаем из исторических источников, интересными художественными деталями и в идентичности друг с другом.

Профессор Эльчин Эфендиев в статье «Легенда продолжается», посвященной поэме Насими, пишет: «Я думаю, что один из лучших аспектов поэмы «Насими» заключается в том, что историчность носит здесь условный характер. С точными историческими цифрами, историческими личностями, с описанием действительно происходящих событий, исторические колориты идентифицируют содержание поэмы Габиля, которая не знает времени, временных рамок» $(12$, с. 538$)$

В поэме Сохраба Тахира «Караван уходит» (13), возникшей из сочетания лирики с эпосом нашло свое художественное воплощение образ Насими в компактных эпизодах и диалогах, а также ряд основных принципов хуруфизма, носителем которого он являлся.

В поэме Расула Рзы «Последняя ночь» (14) важное место занимает лирико-философское творчество. Основная тема поэмы связана с художественным воплощением мыслей Имадеддина Насими в Халебе в ночь перед казнью в темнице. Эту темницу, ставшую конечной остановкой жизни многих невинных, поэт характерными деталями и эпизодами показал как пространство бесправия и несправедливости. В поэме, внутренний мир Насими, его духовная сила, были раскрыты через его личные мысли и мечты, и его литературная позиция основывалась на его беседах с тюремными надзирателями. Насими, который перелистывает книгу тяжелой и тоскливой жизни, с любовью вспоминает родную страну, вспоминает Ширван, Баку, Тебриз, Нахчыван, Каспий и вспоминает горькие годы своей родины. Каспий, горькие и сладкие времена тех дней, которые прошли на родине. Он слышит звуки своих смелых последователей «Я-истина». Но уже конец пути. Жизнь поэта-патриота на чужбине преждевременно будет завершена. Поэма «Последняя ночь» в целом полна и совершенна. Здесь фрагментарные сюжеты сочетаются с лирическими отступлениями, а философские толкования с художественными деталями. Художественный язык, стилистические особенности произведения соответствуют характеру темы. Также имеется полноценное и оригинальное художественное описание и использование средств выражения. Интерес вызывают и символические семантики. 
Поэма Наби Хазри «Горы, на которые смотрел мой дед» (15) создана литературным почтением памяти Имадеддина Насими. Впервые произведение было передано читателям в 1976 году в 6-м номере журнала "Азербайджан". После названия «Горы, на которые смотрел мой дед», в скобках имеется запись «Встреча в Халебе», что означает второе название поэмы и звучит непосредственно с тематикой. Так, в книге представлены рисунки, связанные с приездом Наби Хазри в Халеб, посещением могилы Насими, монологи, посвященные ему, некоторые мнимые беседы с мастером. Как пишет профессор Рафик Юсифоглу: «В поэме ««Горы, на которые смотрел мой дед», тенденция раскрыть характер исторической личности стоит на заднем плане, а мысли поэта находятся на переднем плане» (16, с.131)

Напоминая о своих походах в различные страны Востока по бессмертным следам Имадеддина Насими, Наби Хазри на своем языке подчеркивает духовное бессмертие поэта. Следующие разделы также поэтически осмысливают действия и поступки нашего поэта Насими, его искусство и его личность и вечность, пропагандирующие повышение прав человека через духовное совершенство: в 2019 году в Баку, в «Литературной газете» поэт Балаяр Садиг в нео-поэме «Субъект букв» все это донес до читателей (17). В этой поэме, посвященной 650-летнему юбилею Имадеддина Насими, основное место занимают мысли Насими и других хуруфистов о символическом толковании букв и цифр.Таким образом, Балаяр Садиг старается осмыслить значение образа поэта-мыслителя Насими.

Наряду с азербайджанской поэзией, в художественной прозе существует ряд ценных произведений об Имадеддине Насими. В таких произведениях, эпоха, среда, жизнь, мировоззрение, личность, борьба за истину мыслителя представляются в широком эпическом плане и красочными художественными средствами.

Исторический роман Исы Гусейнова "Машхар” (Страшный суд), рассказывающий об эпохе жизни, среде Имадеддина Насими, о борьбе за истину, вопросы истории и современности, художественно-философское представление прошлого, основные ценности образа Насими, тематические, проблематические и поэтические особенности романа в целом, имеет особое значение в исторической прозе.

Историко-философский роман Исы Гусейнова “Махшар" (18) рассказывает о событиях, произошедших в XIV веке во время захватнических походов Тимура, о необычной борьбе великого философа Востока Фазлуллаха Наими и великого хуруфизского поэта Имадеддина Насими за человека и человечество. Освещается роль Насими в этой борьбе. В произведении также описываются интересные политические конфликты, столкновение политических интересов и разрушение человеческих нравственностей. Роман посвящен Азербайджану конца XIV века. В то же время были разъяснены интересные моменты между Теймуром и Насими и между Насими и народом. Все эти события эпохи были отражены Исой Муганной в своеобразном виде. Также отражены исторические события, художественные сюжеты нашего ближнего и далекого прошлого.

Интересным примером поэзии является роман ученого-историка, писателя Махмуда Исмаила (Исмаилова) «Между двумя огнями» (19), посвященный эпохе, жизни и среде Имадеддина Насими. В дилогии привлекает внимание современность и историчность, художественное воплощение проблемы мастера и времени, идейно-художественные особенности произведения, мир образов, сюжетно-композиционные свойства, особенности стиля и др. В произведении наряду с образом Насими созданы образы исторических личностей того времени, в широком плане одушевлялась общественно-политическая картина Азербайджана. Творчество Насими носило бунтарский характер, оно призывало к борьбе с социальной несправедливостью, насилием над личностью, тиранией и жестокостью правителей. Его стихи воспевали красоту и разум человека, служили освобождению личности от всякого рода условностей, отказу от аскетизма, фанатизма и религиозных догм.

Не только мужественная смерть Насими за свои убеждения, но, может быть, еще и то, что в своих произведениях поэт выразил большую любовь к человеку, веру в его могущество и творческие силы, мастерски сумел высказать свои прогрессивные идеи на языке высокого искусства.

Слава о Насими не увядает даже спустя века, интерес к нему со временем не ослабевает, а наоборот возрастает. И не секрет, что будущим поколениям он нужен и интересен больше, чем своему веку, своим современникам. 
Выводы. В ходе исследования были рассмотрены произведения, написанные в различных жанрах, которые сыграли большую роль в идейно-художественной эволюции азербайджанской литературы, освещали жизненную путь творчества Насими. В статье широко проанализированы литературные произведения, посвященные Насими, которые до сих пор не известны широкой аудитории читателей. В Насиминской лирике жанр-стиль характеризуется эволюцией и новаторским своеобразием.

Каждое из этих произведений, посвященных творчеству Насими, является также историко-литературным произведением и носит в себе историко-информационный груз. Произведения, посвященные Насими, не ограничились только его жизнью и творчеством, но и одушевили политико-историческую картину того времени, в котором жил поэт.

Каждый из этих произведений, посвященных Насиминской лирике, характеризующийся эволюцией жанра-стиля и своеобразным новаторством, оставив большой след в азербайджанской литературе, создает большие возможности для продолжения и расширения научных исследований по наследию Насими.

\section{ЛИТЕРАТУРА}

1. Набиев Б.А. В свете слова Насими. Баку: Карабах, 2009

2. Габиббейли И. Поэт, который не вмешается в мир. Газета «Азербайджан», Баку, 2019, 16 января, № 11

3. Мафтун А. Стихи. Баку: Азернешр, 1959

4. Ашуров Ф. Насими. Журнал «Азербайджан», 1973, №8, с.93-130

5. Араслы Г.М. Имадеддин Насими. Баку: Азернешр, 1972

6. Вахабзаде Б.М. Фарьяд. Баку: Азербайджан, 1995

7. Гараев Ю.В., Салманов Ш.М. Совершенство поэзии. Баку: Язычи, 1985

8. Ягуб М.С. Мельница эпохи. Баку: СБС, 2012

9. Салахзаде А.Б. Статуя огня. Баку. Гянджлик, 1970.

10. Габиль. Насими, Баку: Язычы, 1980

11. Гусейнов А. Утренние размышления. Газета «Литература и искусство», 1980, 1 августа, № 31

12. Эльчин. Творческие проблемы нашей литературы. Баку: Техсил, 1999

13. Тахир С. Караван уходит. Журнал «Азербайджан», Баку, 1973, №8, с. 152-155

14. Рза Р. Избранные произведения, в 5-и томах, 4-ый том. Баку: Издательство Ондер, 2005

15. Хазри Н.А. Избранные произведения, в 4-х томах, 4-ый том, Баку: Язычы, 1984

16. Юсифоглы Р. Художественные особенности азербайджанской поэмы. Баку. Издательство АГПУ, 2010

17. Садиг Б. Субъект букв. «Литературная газета». Баку, 27 апреля 2019. №14

18. Гусейнов И.М. Махшар. Баку: Гянджлик, 1978

19. Исмаил М. Между двумя огнями. Баку: «Гянджлик», 1993. 